\title{
Global business and human rights
}

\author{
by A F M Maniruzzaman
}

"Companies have bodies, but they have no souls; if no souls, no consciences" - John Pollexfen

I nternational law is unclear on whether corporations have any international obligations to protect human rights, or any such obligations that relate to business can be directly imposed on them.

Both the Human Rights Watch's annual world report 2006 and the interim report of the Special Representative of the UN Secretary-General on the issue of human rights and transnational corporations and other business enterprises are now out, and these provide ample food for thought about global business and its relationship to human rights.

Transnational business operations across the globe are a common phenomenon, and are increasingly more so in the age of globalization. While such operations are considered to be blessings for economic growth and development in the host countries concerned in particular, and for the global economy in general, there are frequent allegations against transnational corporations (TNCs) of violation of human rights, environmental degradation and so on. Such allegations abound lately, for example, that against Exxon Mobil Corp in Indonesia, Fresh Del Monte Produce Inc in Guatemala, ChevronTexaco Corp in Nigeria and in Ecuador, Unocal in Myanmar, and Occidental Petroleum Corp, Coca-Cola Co and the coal miner Drummond Co in Colombia, to name but a few.

Non-governmental organisations (NGOs) rather than host governments eloquently express the affected peoples' concerns and grievances in international forums and take actions against the culprits in various relevant jurisdictions. Recently this appears to be a growing tendency. But the victims and their supporters apparently stumble in the forecourt of the law that is very shaky in this respect. This phenomenon poses a big challenge for international law, in general, and international human rights law, in particular, more than ever before in the progressively globalized world.

Just imagine the scenario for a moment: there are some 70,000 transnational firms operating in the world today, together with roughly 700,000 subsidiaries and millions of suppliers connected through distributed networks across the globe. The activities of these entities certainly have a great impact on the lives and conditions of millions of people around the world and the world economy as a whole.

\section{NEED FOR CLARIFICATION}

The problem with traditional international law is that the responsibility for the protection of human rights lies with the state and not with any business entity. The issue thus arises whether corporations have any international obligations to protect human rights, or any such obligations that relate to business can be directly imposed on them. As international law is not yet clear on this matter, the dilemma comes to the forefront in quest for a solution to the ever-demanding issue. Just ask one's conscience if one would invest one's pension savings in a project that causes human rights violations or abuse in any form, such as forced labour, child labour, destruction of human habitat and indigenous population, rape and brutality, mayhem in general, or even ethnic cleansing and other untold miseries.

The conscientious negative answer to this behooves one to think of monitoring corporate behaviour even beyond the debate of state versus transnational corporations' responsibility for the protection of human rights. It is not only corporate accountability for human rights but also corporate partnership with the host state in the protection of human rights that is the pressing need of our time, given that TNCs' global reach, capacity and influence surpass the effectiveness of many nation states. Although over the past 10 years or so corporate social responsibility (CSR) has blossomed as an idea at the persistent persuasion of the global civil society, and has consequently moved up to the corporate agenda, CSR has not effectively addressed the issue so far. Due to the lack of a solid legal framework in this respect, CSR merely operates as a glossy public relations agenda and a tool for manipulation of corporate image.

Recently, various stakeholders have started to ponder over the matter with great urgency. The recent report of the United Nations Commission on Human Rights on the responsibilities of transnational corporations and related 
business enterprises with regard to human rights notes significant gaps in understanding the nature and scope of the human rights responsibilities of business. The outstanding issues that need detailed study should be urgently identified. In July last year the UN SecretaryGeneral appointed John Ruggie, a Harvard academic, as Special Representative for Business and Human Rights to look into the issues.

What is needed is not just the production of mundane report after report to occupy shelf space, but the understanding of business entities and their willingness to be transparent in their actions. Factors to be taken into account include their genuine goodwill in establishing and respecting human dignity, and offering every help and cooperation with the various stakeholders concerned so that business and human rights matters are well balanced and the world becomes a much better place in the age of globalization. The list of stakeholders takes in states, shareholders, peoples affected by TNC activities, employers' and employees' associations, relevant international organizations and agencies, treaty monitoring bodies and non-governmental organizations. However, such goodwill is sometimes in short supply, hence the urgent need to formulate a set of legally binding rules - a set of global standards - which should be the yardstick against which the actions of corporations need to be measured. Furthermore, the ways and means of the governance of human rights in the borders of states should be explored in the days ahead.

On an encouraging note it can be reported that while launching its annual report in Washington lately the Human Rights Watch has said that TNCs have responded favourably to calls for binding human rights standards in the corporate sector, as voluntary guidelines have failed to repair the bad image of the corporate world. Multinational executives have also started to question the wisdom of selfregulation and voluntary codes of conduct on a moral plane. E

- The Human Rights Watch's annual world report 2006 can be accessed at http://www.hrw.org/english/docs/ 2006/01/13/global12428.htm and the interim report of the Special Representative of the UN SecretaryGeneral on the issue of human rights and transnational corporations and other business enterprises is also available (at E/CN.4/2006/97 (22 February 2006)).

Professor Dr A F M Maniruzzaman

Professor of International Law and International Business Law at the University of Portsmouth

\section{IALS Events}

Thursday, 2 November, 6-7pm

\section{JUSTICE KEITH MASON}

President of the New South Wales Court of Appeal, Australia; Inns of Court fellow at the Institute of Advanced Legal Studies

The intent of legislators: how judges discern it and what they do if they find it

"Ambiguous legislation may stem from technical slips in the law-making process, conscious ambiguity by policy makers, inability to predict problem areas, and other badges of humanity. Law-making is at its messiest when the Executive is least able to dominate Parliament.

Judicial caution with extrinsic aids to the interpretation of statutes, including speeches in Parliament, is justified on both pragmatic and constitutional grounds.”

This lecture is eligible for one Law Society and one General Council of the Bar CPD hour. Admission free all welcome. This lecture will be held at the IALS. Please reply to Belinda Crothers, IALS, 17 Russell Square, London WC1B 5DR (tel: 0207862 5841; email: Belinda.Crothers@sas.ac.uk).
Friday, 10 November, 6pm

The Institute of Advanced Legal Studies and Chatham House

\section{The 2006 Sir William Dale Memorial Lecture}

\section{Venue: Chatham House, 10 St James's Square, London SW1}

\section{PROFESSOR KADER ASMAL}

Member of Parliament, National Assembly, South Africa The South Africa Constitution and the transition from apartheid: legislating the reconciliation of rights in a multicultural society. Chair: PROFESSOR JEFFREY JOWELL QC, University College London

Admission free - all welcome. Please reply to Linda Bedford, Chatham House, 10 St James's Square, London SW1Y 4LE (tel: 0207314 2761; email:

lbedford@chathamhouse.org.uk). Other enquiries to Belinda Crothers, IALS, 17 Russell Square, London WC1B 5DR (tel: 0207862 5841; email:

Belinda.Crothers@sas.ac.uk). 